\title{
Aligning Strategic Human Resource Management To Human Resources, Performance And Reward
}

\author{
Melody Brauns, Durban University Of Technology, South Africa
}

\begin{abstract}
In a rapidly changing business environment, one may recognise the words "the only thing constant in life is change" by French author Francois de la Rockefoucauld. Yet, with on-going change, it can be difficult to know what to do and how to do it. The world out there is harsh and competition is fierce. Indeed, the world is changing at a rapid pace. Therefore, both public and private sectors have to plan for the future and prepare for any unforeseen circumstance. This paper will discuss the link between Strategic Human Resource Management, Human resources, Performance and Reward, what we know, and the future direction of Strategic Human Resource Management.

Strategic Human Resource Management involves making those decisions that define the overall vision, mission, core values and objectives of the organisation, thus determining the most effective utilisation of its resources. Walker (1992: 16) states that Strategic Management enables managers to respond to environmental changes based on a defined business mission, vision and values. Strategies are directional plans that guide management actions in the pursuit of opportunities. In essence, strategies point the way for the most promising changes. They are plans that give direction and address people related business issues. Human Resource strategies are important because they help determine how to manage people in relation to business strategies. Strategic Human Resource Management aligns Human Resources, which is necessary for the success of the organisation.
\end{abstract}

Keywords: Strategic Human Resource Management; Performance; Reward; Human Resources; Strategic Management; Organisations; Motivation

\section{INTRODUCTION}

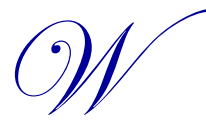

ithout a strategic plan, management and the organisation, as a whole, would not be in a position to achieve its goals and objectives as outlined in the organisation's strategic plan. Challenges surrounding Strategic Human Resources are the responsibility of every manager within the department and not as in the past where human capital issues were the sole responsibility of the personnel department.

The way in which people are managed within organisations needs to be aligned with the strategy of the business. The management of Human Resources can no longer be viewed as an activity relegated to Human Resource staff. It is a fundamental activity in the mainstream of formulating and implementing business strategy. This paper, therefore, aims at aligning Strategic Human Resource Management with Human Resources, Performance, and Reward.

\section{DEFINING STRATEGIC HUMAN RESOURCE MANAGEMENT AND STRATEGIC MANAGEMENT}

The definition of Strategic Human Resource Management, according to Johnson and Scholes (2002: 10), can be defined as "the direction and scope of an organisation over the longer term, which ideally matches its 
resources to its changing environment, and, in particular, to its markets, customers and clients to meet stakeholders' expectations".

Another widely used definition of Strategic Human Resource Management has been provided by Ellers and Lazenby (2007: 1) who assert that it is "the process whereby all the organisational functions and resources are integrated and coordinated to implement formulated strategies in order to achieve the long-term objectives of the organisation and therefore gain a competitive advantage through adding value for the stakeholder". Competitive advantage, in this context, refers to the edge that an organisation has over another, particularly what makes one firm better than the other or why some companies out-perform their competitors.

Boxall and Purcell (2003: 44) define Strategic Management as a process of strategy making, of forming and reforming its strategy over a period of time. This is amplified by David (2003: 5) who refers to Strategic Management as "the art and science of formulating, implementing and evaluating cross-functional decisions that enable an organisation to achieve its objectives". To a large extent, this definition implies that Strategic Management focuses on integrating core functions to achieve organisational success. Strategic Management, as a process, consists of the following three stages:

- $\quad$ Strategy formulation

- $\quad$ Strategy implementation

- $\quad$ Strategy evaluation (David, 2003: 5)

Strategy formulation includes developing a vision and mission, identifying an organisation's external opportunities and threats, determining internal strengths and weaknesses, establishing long-term objectives, generating alternative strategies, and choosing particular strategies to pursue. Strategy formulation issues include deciding what new business to enter, what business to abandon, how to allocate resources, whether to expand operations or diversify, whether to enter international markets, whether to merge or form a joint venture, and how to avoid a hostile takeover (David, 2003: 5).

Strategy Implementation requires a firm to establish annual objectives, devise policies, motivate employees, and allocate resources so that formulated strategies can be executed. Strategy implantation includes developing a strategy supportive culture, creating an efficient organisational structure, reducing marketing efforts, preparing budgets, developing and utilising information systems, and linking employee compensation to organisational performance. He continues that strategy implementation is often called the action stage of Strategic Management (Davis, 2003: 5).

Strategy Evaluation is the final stage in Strategic Management. Managers need to know when particular strategies are not working well; strategy evaluation is the primary means of obtaining this information. All strategies are subject to future modification because external and internal factors are constantly changing" (David, 2003: 6).

\section{ALIGNING STRATEGIC HUMAN RESOURCE MANAGEMENT AND HUMAN RESOURCE MANAGEMENT}

There is a growing realisation among organisations to align its Human Resource practices with corporate strategies to meet the needs of its business in order to gain strategic advantage from its Human Resources. Human Resource Management is significantly aligned to Strategic Human Resource Management and is one of the fundamental policy objectives to ensure that Human Resource policies and practices are applied by managers as part of their everyday work. Ellers and Lazenby (2007: 256) maintain that successful strategy implementation can be achieved if resources are allocated in a manner that supports the organisations long- and short-term goals, chosen strategy, and structure.

More importantly, Ehlers and Lazenby (2007: 257) argue that the knowledge era is important for strategy implementation in that employees are allocated the most important task in implementing the strategy. Organisations can no longer generate profits without the ideas, skills, and talent of knowledgeable workers. Technologies, factories, natural resources, and capital are no longer difficult to obtain and are increasingly less important in 
developing and sustaining a competitive advantage for the organisation. While capital is becoming less scarce, the opposite may be said of talent and skills, especially in developed countries. This issue may be one of the reasons for the rise in Chief Executive Officers (CEO's) and executives' compensation in the last decade. Demand for talented and highly skilled knowledgeable workers is stripping supply.

This approach, emphasising Human Resources, echoes Nel, Werner, Haasbroek, Poisant, Sono and Schultz's (2008: 553) comment on Human Resources practices, which emphasises that Human Resources practices may be successful if they are aligned with the strategic objective of the business, make business sense, and are focused on business operations. Nel et al. (2008) concludes that the strategic partner role focuses on aligning Human Resource strategies (including policies and procedures) with the business strategies and the execution thereof.

Armstrong (2006: 124) is of the opinion that the distinction between Strategic Human Resource Management and Human Resource Management is underpinned by a philosophy that supports the Strategic Management of Human Resources in accordance with the plans of the organisation concerning the future direction it wants to take. As a result of this process, a stream of decisions over time emerges to form the pattern adopted by the organisation for managing its Human Resources to identify areas in which specific Human Resource strategies need to be developed.

Because the world has become a global marketplace, the focus nowadays lies on Human Resource Management and the successful integration of strategies within an organisation. The emphasis is on managing people within the employer-employee relationship, maintaining that staff is the major reason for the success of an organisation. The Human Resources of an organisation represent one of its largest investments, illustrating that employees should be supported in reaching their full potential and thus enjoy sound quality of life and job satisfaction (Nel et al., 2008: 6).

\section{DEFINING PERFORMANCE MANAGEMENT}

The Oxford Dictionary defines performance as carrying out, accomplishing, or fulfilling an action, task or function, whilst Armstrong (2006: 497-499) defines performance as the achievement of quantified objectives which is not only a matter of what people achieve but how they achieve them. More importantly, performance must examine how results are achieved because this provides the required information to consider what needs to be done to develop those results. Armstrong argues that one of the fundamental purposes of performance management is to align individual and organisational objectives. Alignment can be accomplished by a flowing process so that objectives can cascade from the top, thereby allowing team or individual objectives to be defined in light of these higher level goals.

Carrell and Elbert (2000: 224) suggest that Performance Management is a box of 'tools'. This opinion is developed by pointing out that management uses a variety of 'tools' to guide, control and improve the performance of employees. Tools, such as reward systems, leadership, job design, training efforts, and performance appraisals, can be regarded as part of an effective human performance management system and a significant part of most managers' jobs.

\section{CHARACTERISTICS AND PURPOSE OF PERFORMANCE MANAGEMENT}

Price (2007: 452) observes that the Performance Management system is owned and implemented by line managers, which is amplified by the role of Human Resource specialists to aid and advise line managers on the development of the Performance Management systems. Performance Management is characterised by the following:

- A clear statement of what is to be achieved by the organisation

- $\quad$ Individual and group responsibilities support the organisations goals

- $\quad$ All performance is measured and assessed in terms of those responsibilities and goals

- $\quad$ All rewards are based on employee performance

- Organisational structured, processes, resources, and authority systems are designed to optimize the performance of all employees 
- There is an on-going effort to create and guide appropriate organisation goals and to seek newer, more appropriate goals (Price, 2007: 452)

The purpose of Performance Management is a means of achieving improved results from the organisation, groups, teams, and individuals by understanding and managing performance within an agreed framework. It is a process of establishing and understanding what is to be achieved, as well as an approach to managing and developing people in a way which increases the achievement of short- and long-term objectives. DeCenzo (2005: 246) echoes Armstrong's purpose of Performance Management by asserting that without proper two-way feedback about an employee's effort and its effect on performance, there is a risk of decreasing the employee's motivation.

\section{PERFORMANCE MANAGEMENT SYSTEMS}

The strategic aspects of performance assessment; namely, the three C's - consistency, coordination, and control - are represented in the integration of appraisals and performance-related pay procedures within performance management systems (Price, 2007: 450). The following are regarded as the functions of a performance management system:

- $\quad$ Reinforcement of the organisations values and norms

- Integration of individual objectives with those of the organisation

- $\quad$ Allowing individuals to express their views on the job

- $\quad$ Providing the means for managers and staff to share their expectations of performance (Armstrong, 1991: 162).

Performance Management Systems comprise of various activities, suggesting that it entails more than simply reviewing what an employee has done. DeCenzo (2005: 246) develops this point by recommending that the Performance Management System must fulfil several purposes, taking into consideration it is often hindered by difficulties in how they operate. Performance Management system should include the following actions:

- $\quad$ Develop clear job descriptions

- $\quad$ Select appropriate people with an appropriate selection process

- $\quad$ Negotiate requirements and accomplishment-based performance standards, outcomes and measures

- $\quad$ Provide effective orientation, education, and training

- $\quad$ Provide on-going coaching and feedback

- $\quad$ Conduct quarterly performance development discussions

- $\quad$ Design effective compensation and recognition systems that reward people for their contributions

- $\quad$ Provide promotional/career development opportunities for staff

- $\quad$ Assist with exit interviews to understand why valued employees leave the organisation (Heathfield)

\section{REWARD}

Why is reward so important? This is a simple question that perhaps has complex answers. Could it be that people only work for reward? Is this the reason why we wake up in the morning? For some, reward may be in the form of financial gain and, for others, it may be a question of a good company to work for, status, and even mental stimulation. The question of whether money can motivate people to work has been a contentious issue for both employer and employee alike. Here we follow Maslow (1954) who pointed out the hierarchy of needs as a motivational theory, laying emphasis on the fact that higher-order needs gradually become more important when lower-order needs have been satisfied. Herzberg (1966) observed that remuneration is a significant source of satisfaction when it is seen as a form of reward or recognition. Vroom's (1964) expectancy theory emphasizes the need for organisations to relate reward directly to performance and to ensure that the reward provided is desired and deserved by the recipients.

Bratton and Gold (2007: 358) point out that reward pertains to "all of the monetary, non-monetary, and psychological payments that an organization provides for its employees in exchange for the work they perform'. 
Swanepoel, Erasmus, and Schenk (2008: 476) distinguish between intrinsic and extrinsic rewards. Intrinsic rewards are self-administered and are associated with the job itself, such as the opportunity to perform meaningful work, experience variety and receive feedback on the work results. In other words, it is the satisfaction that a person derives from doing the job. Extrinsic rewards include those that an employee gets from sources other than the job itself. This involves benefits obtained as a result of doing the job, such as promotion or remuneration.

Performance and reward are closely aligned due to the fact that work can be more rewarding if it gives you what you want. As a result, an employee is likely to perform at a high level if the work is rewarding; hence, reward is an important component of Human Resource Management. According to Price (2007: 467), the term reward management encompasses both the strategy and the practice of remuneration systems. There are two basic types of remuneration schemes, although many organisations have systems that comprise of both elements:

- $\quad$ Fixed level of pay - wages or salaries that do not vary from one period to the next except by defined pay increases, generally on an annual basis. There may be scales of payments determined by age, responsibility or seniority. Most 'white collar' jobs were paid in this way until recently.

- $\quad$ Reward linked to performance - the link may be daily, weekly, monthly, or annually. Payment for any one period varies from that for any other period, depending on quantity or quality of work (Price, 2007: 467).

Armstrong (2002: 10) suggests that an employee reward system is made up of an organisation's integrated policies, processes, and practices aimed at rewarding its employees in terms of skill, competence, and their market worth. An employee reward system is established within the framework of the organisation's reward philosophy and polices which take into account the appropriate types and levels of pay, benefits, and other forms of reward.

\section{AIMS OF EMPLOYEE REWARD - FROM AN ORGANISATIONS POINT OF VIEW AND FROM AN EMPLOYEE POINT OF VIEW}

Armstrong (2002: 13) claims that "a reward system expresses what the organisation values and is prepared to pay for". It is regulated by the need to reward good performance and to get the right message across about what is important from the organisation's perspective. The specific aims of employee reward are to:

- $\quad$ Help to attract, retain, and motivate high quality people

- Play a significant part in the communication of the organisations values, performance, standards, and expectations

- Encourage behaviour that will contribute to the achievement of the organisations objectives and reflect the 'balanced score card' of key performance drivers

- $\quad$ Underpin organisational change programmes concerned with culture, process, and structure

- Support the realisation of the key values of the organisation in such areas as quality, customer care, teamwork, innovation, flexibility, and speed of response

- $\quad$ Provide value for money - no reward initiative should be undertaken unless it has been established that it will add value, and no reward practice should be retained if it does not result in added value (Armstrong 2002: 14).

Armstrong (2002: 14) states that from an employee's point of view, the reward system should:

- Treat them as stakeholders who have the right to be involved in the development of the reward policies that affect them

- Meet their expectations that they will be treated equitably, fairly, and consistently in relation to the work they do and their contribution

- $\quad$ Be transparent - they should know what the reward policies of the organisation are and how they are affected by them (Armstrong, 2002: 14). 


\section{CONCLUSION}

The above discussion indicates that Strategic Human Resource management is indeed closely aligned with Human Resource management, Performance, and Reward. Strategic Human Resource management is the core component of which Human Resource management, Performance, and Reward are secondary. Without Strategic Human Resource management, the Human Resource function cannot perform at its optimum.

\section{AUTHOR INFORMATION}

Melody Brauns graduated Honours from Durban University of Technology in South Africa and thereafter completed a full Masters dissertation. She is currently pursuing her Ph.D. studies at the University of KwaZuluNatal where her area of specialisation is in the public sector. To date, she has attended two conferences where one article has been published and another pending. Melody lectures Public Management and also coordinates workintegrated learning for Public Management students. E-mail: melodyb@dut.ac.za

\section{REFERENCES}

1. Armstrong, M. 1991. A handbook of Personnel Management Practice. London: Kogan Page.

2. $\quad$ Armstrong, M. 2002. Employee Reward, $3^{\text {rd }}$ edition. London: Cromwell Press.

3. Armstrong, M. 2006. Armstrong's Handbook on Human Resource Management Practice, $11^{\text {th }}$ edition. London: Kogan Page.

4. Boxall, P.F. and Purcell, J. 2003. Strategy and Human Resource Management. New York: Palgrave Macmillan.

5. Bratton, J., and Gold, J. 2007. Human Resource Management: Theory and Practice, $4^{\text {th }}$ edition. Houndmills: Macmillan.

6. $\quad$ Carrell, M.R and Elbert, N.F. 2000. Human Resource Management, $8^{\text {th }}$ edition. Orlando: Dryden Press.

7. David, F.R., 2003. Strategic Management: Concepts and Cases. New Jersey: Prentice Hall.

8. DeCenzo, D.A. 2005. Fundamentals of Human Resource Management, $8^{\text {th }}$ edition. New York: John Wiley and Sons.

9. Ehlers, M.B., Lazenby, J.A.A., 2007. Strategic Management: South African Concepts and Cases. Pretoria, Van Schaik.

10. Heathfield, S.M. (n.d) Performance Management [online]. Available at: http://humanresources.about.com/od/glossary/g/perform-mgmt.htm [Accessed 18 April 2013].

11. Johnson, G. and Scholes, K. 2002. Exploring corporate strategy, $6^{\text {th }}$ edition. London: Prentice Hall.

12. Nel, P.S., Werner, A., Haasbroek, G.G., Poisat, P., Sono, T. and Schultz, H.B. 2008. Human Resources Management, $7^{\text {th }}$ edition. Cape Town: Oxford University Press.

13. Price, A. 2007. Human Resource Management in a Business Context, $3^{\text {rd }}$ edition. London: Thompson Learning.

14. Swanepoel, B.J., Erasmus, B.J. and Schenk, H.W. 2008. South African Human Resource Management. Theory and Practice $4^{\text {th }}$ edition. Cape Town: Juta \& Co Ltd.

15. Walker, J.W., 1992. Human Resource Strategy. USA, McGraw-Hill. 